\section{Geriatric Care in Ayurved: Evidence Based Review}

\author{
Rakesh Shukla* \\ BAMS, Shri Balahanuman Ayurvedic College, Gujarat, India
}

\begin{abstract}
The prevalence of illness increases as we age; at the same time, life expectancy decreases. Ayurveda, has got the potential for prevention of diseases by health promotion and management of diseases occurring in old age. We discuss lifestyle recommendations such as smoking cessation, exercise, Yoga, Rasayana therapy and good nutrition. Jarachikitsa or Rasayana is a unique therapeutic methodology to delay ageing and to minimize the intensity of problems occurring this degenerative phase of one's life. Future aging can be reduced before the occurrence of old age. In fact the ideal time for treating the geriatric problems is youth. Adherence to discipline in youth keeps the geriatric problems away. By adopting a healthier lifestyle, the risk of noncommunicable chronic disease can be reduced. The Government of India launched a national campaign to popularize the strength of Ayurveda and Yoga in geriatric health care. It is the demand of the hour to develop an effective holistic protocol for geriatric care by combining Rasayana, Panchkarma, Dietetics, Ayurvedic medicines, lifestyle and Yoga is timely.

Keywords: Ayurveda; Geriatric; Rasayana; Yoga
\end{abstract}

\section{Introduction}

Ageing is a process of physical, psychological and social change in multi-dimensional aspects. The world's elderly population is increasing. By 2050, one-fifth of the world will be older than 65 years. In India, they will be about 113 million elderly by $2016[1,2]$. Ayurveda has the potential for disease prevention by health promotion and noncommunicable disease prevention. The focused branch Rasayana (rejuvenation) or Jarachikitsa promote healthy longevity. Jarachikitsa and Rasayana methodologically delay vruddhavastha (ageing) and reduce geriatric degeneration. Vruddhavastha begins at $60-70$ years $[3,4]$.

\section{Problems in Vruddhavastha}

Advancement of age usually creates numerous problems in the individual. Geriatric problems may be mainly divided into four categories: physical, psychological, emotional, and social.

${ }^{*}$ Corresponding author: Rakesh Shukla, BAMS, Shri Balahanuman Ayurvedic College, Gujarat, India, Tel: +91 9033656148; E-mail: drrakesh.ayur@gmail.com

Citation: Shukla R (2015) Geriatric Care in Ayurved: Evidence Based Review. J Altern Complement Integr Med 1: 005.

Received: July 15, 2015; Accepted: October 21, 2015; Published: October 30, 2015

\section{Physical problems}

The following are some very common physical disorders of the old age:

- Cardiovascular - hypertension, MI, CCF

- Respiratory - asthma and bronchitis

- Musculoskeletal - osteoporosis, spasm, drooping shoulder

- Gastro-intestinal - dyspepsia and flatulence

- Genito-urinary - nocturia, prostate enlargement

- Locomotor system - osteoarthritis, rheumatoid arthritis, gout

- Endocrinological - diabetes is one of the major endocrinological problems found in old age.

- Ophthalmic - senile cataract and glaucoma are very common in old people

- Hearing - loss of hearing and hard hearing are the major hearing problems of old age

- Nervous - insomnia is commonly found old age problems

- Problems of hair - hair loss and baldness

- Cancer - Cancer incidence and severity increases with age

- Menopausal - in addition to all these, ladies experience menopausal health disorders

\section{Psychological problems}

Dementia is often noticed in old people. There are 24.2 million people living with dementia worldwide, with 4.6 million new cases every year [5]. Sense of being neglected in the family is a common complaint of the aged. Depression is the most harmful and widely noticed psychological complaint of the senior citizens [6].

\section{Social issues in elderly}

Fighting geriatric problems is not the sole responsibility of the senior citizen alone. The family and the society have their share of responsibility in the fight. Marital status, financial status, work history, education, responsibilities, living atmosphere and arrangements are the prime issues to be considered while addressing the issues of elderly. Loss of key support like death of spouse/siblings, retirement, relocation and financial deterioration. Due to changing phenomenon in India like nuclear family system and urban migration of the people, the rural elderly people are the most sufferers due to absence of family support. In addition, physical abuse, psychological abuse, neglect, financial abuse are common on elderly patients, which further add to the agony. These changes may cause multiple problems with regard to physical, social, mental wellbeing.

\section{Spiritual issues in the elderly}

Active involvement in religious activities helps the patient in active life style and socializing, which in-turn minimize the problems arising from isolation and chronic diseases. Interaction with people will also increase the awareness and hence there will be possibility for early detection of the diseases and better treatment compliance. 
Religious and spiritual persons tend to recover from diseases more quickly [7]. Elderly persons attending religious activities remain motivated to stop addictions like smoking, alcohol, which help in better health and social status. The common spiritual interventions are praying, reading religious books, visiting auspicious places, attending religious rituals and meditation. Try to keep the mind and personality always pleasant. This will increase the socialization, reduce isolation and promote the feeling of belongingness.

\section{Special Considerations in Old Age}

Multiple illnesses (medical and psychiatric), multiple problems (social, financial, family), communication difficulty, sensory impairment, need for collateral sources of information, risk of drug side effects, atypical presentation of disease.

\section{Preventive and Curative Measures for Geriatrics}

Acharya Charak says "He, who treats the disease before its commencement or at an early stage, experiences long-lasting happiness". Geriatric problems are best confronted by preventive measures than curative ones. Therefore geriatrics has to be treated much before the commencement of old age. The ideal time for treating the old age problems is youth. Discipline in young age prevents geriatric problems. By adopting a healthier lifestyle, the risk of a whole range of diseases can be reduced. These factors are diet and nutrition, exercise, weight, smoking and alcohol, social activities.

\section{Diet and nutrition}

With increasing age, people become more prone to malnutrition for many reasons [8] including - Arochaka (Anorexia), Smritinash (Dementia), Manoavasada (Depression), Stroke, Kampavata (Parkinson disease) and other neurological disorders, delayed gastric emptying. The diet should be regulated taking into account the habitat, season, age, and according to one's digestive capacity [9]. Following points may be considered while planning/advising dietary and other life style regimen.

- The food should be tasty, nutritious, fresh and good in appearance.

- Too spicy, salty and pungent food should be avoided.

- It should neither be very hot nor very cold.

- Liquid intake should be more frequent and in small amount.

- Heavy food can be prescribed in a limited quantity.

- Heavy food should not be given at night. The proper time for night meals is two to three hours before going to bed. After dinner, it is better to advice for a short walk.

- Heavy physical work should be avoided after meals.

- Mind should be peaceful while eating.

- Eating only whenever hungry and avoidance of over eating.

- Inclusion of sufficient amount of vegetables and fruits in diet.

- Daily intake of vegetable soup and fruit juices.

\section{Concept of Rasayana (rejuvenation)}

Rasayana has broad meaning indicating qualitative and quantitative improvement of dhatu (tissues). Vayasthapana are specialized rasayana drugs that reverse degenerative changes, increase life span with quality health [10]. The main utility of Rasayana therapy is in functional and degenerative disorders that have a chronic or long standing nature. In such cases, in fact, rasayana is the only solution from the point of view of effective management in any system of medicine. Rasayana becomes more fruitful and effective, if it is preceded with suitable Panchakarma (purificatory therapy). The reason we see mixed results in many cases where Rasayana is employed is because of the fact that, either this purification is not done or improperly done. Some evidence based research -

- Butea monosperma root distillate in the management of age related immature cataract: The root distillate drops of Butea monosperma developed as per I.P Standards has shown significant improvement in visual acuity and quality of vision (disturbance in vision viz haziness and diplopia) in the subjects of age related immature cataract $(\mathrm{n}=52)$ [11].

- Guduchi (Tinospora cordifolia) as immunomodulatory agent: Clinical studies of Guduchi (Tinospora cordifolia) have shown significant efficacy in the cases of obstructive jaundice [12].

- Sallaki (Boswelia serrata) in Rheumatoid Arthritis (RA): Sallaki 600 $\mathrm{mg}$ trice daily and $50 \mathrm{mg}$ of diclofenac sodium 3 times in a day were given in treated and control groups respectively for 4 weeks. The efficacy of sallaki was found to be comparable to that of diclofenac sodium in the patients of Rheumatoid Arthritis (RA), who demonstrated predisposition for gastric intolerance with anti-inflammatory medication [13].

- Guggulu (Commiphora wightii) in hyperlipidemia: Cardinal clinical manifestations of disease like precordial pain and dyspnoea were relieved in most of the cases in a clinical study tried with guggulu in the dose of $8 \mathrm{gm} /$ day. Substantial fall in lipid fractions like cholesterol $27 \%$, triglycerides $36 \%$, phospholipids $20 \%$ and free fatty acids $37 \%$ indicated the possibility of regression of atherosclerosis. The reversal of ECG changes substantiated the anti-ischaemic effect of the drug in the treatment of ischemic heart diseases [14].

- Ashwagandha (Withania somnifera) on the process of aging: Root powder of Ashwagandha (Withania somnifera) was administered in the dosage of two tablets three times daily with milk for one year showed statistically significant increase in haemoglobin, RBC count, hair melanin and seated stature and decrease in serum cholesterol and ESR [15].

- Management of hemiplegia by panchakarma: Comparative study of 744 hemiplegics revealed that 552 subjects who received Panchakarma therapy showed significant recovery from illness, with improvement in motor functions and quality of life in comparison to subjects who received Shamana therapy (palliative therapy) alone [16].

- Multi-facetted protective role of Chyawanprasa: Chyawanprasa showed significant immunomodulatory activity (decrease in Ig G, C3 and C4 levels in patients of recurrent cough and cold), cytoprotective action (cancer patients receiving radiation therapy showed a protective role against radiation induced tissue damage) and Genoprotective action (significant reduction in Mitotic Index (MI) and Chromosomal Aberrations (CA) [17].

- Anti-anxiety effect Mandukaparni (Centell aasiatica), Yastimadhu (Glycyrrhiza glabra) and Jatamansi (Nordostachys jatamansi): A double blind sequential cross over clinical trial with an Ayurvedic compound containing Mandukaparni (Centella asiatica), Yastimadhu (Glycyrrhiza glabra) and Jatamansi (Nordostachys jatamansi) as trial drug, diazepam as control and placebo was carried out on 12 patients of anxiety neurosis. The compound formulation is more effective in enhancing the perceptual discrimination and psychomotor performance over placebo and control drug [18]. 
Other compound formulations that are available in the market with a multipronged action are being listed below: Brahmi Rasayana, Ashwagandha Lehyam, Maha Triphala Ghrita, Triphala Churna, Ashwagandha Churna, Narasimha Rasayana, Agastya Rasayana, Amalaki Rasayana.

\section{Exercise}

Exercise helps to control weight, improve emotional well-being and relives stress, improve blood circulation, flexibility. Regular yogic exercise from youth limits the effects of old age [19].

\section{Benefits of the geriatric yoga:}

- Yoga provides a good balance, blood stream and tissue liveliness thanks to the enhanced flexibility and core stabilization. If the person attends the Geriatric Yoga programme regularly, many problems, which are caused by age, can be prevented [20]

- It is possible to reload the most essential brain functions with the relaxing characteristic of Yoga

- The person gains experience with his own existence, body andmental performance during the sessions in Yoga practices. He learns to control his body. He analyzes his emotional status about his problem. He gains ability to cope with the symptoms faced

- It reduces sympathetic activity with relaxing techniques. Pain, fatigue, depression and stress decrease with relaxing response. Memory becomes retentive [21]

Yoga has found a place as an alternative medicine approach within geriatric and rehabilitation programmes in developed countries in Europe and in the US owing to its countless beneficial effects and it has started to be practiced to improve physical health, to inform, to cope with and to support in various supportive programmes; to help people on issues such as pain, fatigue, stress, nutrition, exercise, sleep and patient caring [22].

The following longevity promoting yogic practices should be performed only under the guidance of qualified Yoga therapist.

Asanas: Surya Namaskar, Pavanamuktasana, Ardha Matsyendrasana, Bhujangasana and Shavasana.

Pranayama: Nadisodhana, Kapalbhati, Bhramari, Neti, Bhastrika and Tratak.

Mudras: Khechari mudra removes diseases and old age problems. Dharana, Dhyana, Swadhyaya and Iswara Pranidhana.

\section{Cutting down smoking and alcohol}

Drinking is linked to liver diseases, stomach ulcers, gout, depression, osteoporosis, heart disease, and hypertension. Sensitivity to the effect of alcohol increases with the age [23].

\section{Social activities}

Mixing with other people of similar age, at similar stage of life or perhaps with similar health concerns, can help people realize that they are not alone. The elderly need not always be seen as care receivers. They can be resource too - Transmitters of culture, care of grandchildren (storytelling, playing), counselors to the young couple, they had vast and varied experiences, helps in problem solving and trouble shooting.

\section{Conclusion}

To live a long and healthy life is every individual's wish. Due to changing lifestyle and thus not able to follow the rules of dietetics human beings have led to an emergence of varied problems for the elderly in India. It is obvious that the process of ageing was elaborately described in ayurvedic texts and a separate medical discipline called Rasayana tantra was developed which described a variety of methods and measures to promote healthy longevity. Undoubtedly, it is the strength of ayurveda in the context of geriatric care Rasayana is a therapy which bestows excellent rasa which ultimately results in promotion of longevity, alleviation of old age and diseases so as to enjoy the full span of life. Government of India has also launched a national campaign to popularize the strength of Ayurveda and Yoga in geriatric health care. It is the demand of the hour to develop an effective holistic protocol for geriatric care by combining Rasayana, Panchkarma, Dietetics, Ayurvedic medicines and lifestyle and Yoga.

\section{References}

1. Ingle GK, Nath A (2008) Geriatric health in India: concerns and solutions. Indian J Community Med 33: 214-218.

2. Dey AB (2007) Handbook of Geriatrics. (1 $\left.{ }^{\text {st }} e d n\right)$, Paras Medical Publisher, Hyderabad, India. Pg no: 118.

3. Ambikadutta S (2007) Sutra Sthan $35 / 35$, Sushruta Samhita. Chaukhambha Sanskrit Sansthan, Varanasi, India 1: 134.

4. Kashinath S, Gorakhnath C (2004) Viaman Sthan 8/122, Charak Samhita, Part I. Chaukhambha Bharati Academy, Varanasi, India. Pg no: 782.

5. Ferri CP, Prince M, Brayne C, Brodaty H, Fratiglioni L, et al. (2005) Global prevalence of dementia: a Delphi consensus study. Lancet 366: 2112-2117.

6. Fiske A, Wetherel JL, Gatz M (2009) Depression in older adults. Annu Rev Clin Psychol 5: 363-389.

7. Koenig HG, George LK, Titus P (2004) Religion, spirituality, and health in medically ill hospitalized older patients. J Am Geriatr Soc 52: 554-562.

8. Stratton RJ. Green CJ, Elia M (2003) Disease-related malnutrition: an evidence-based approach to treatment. CABI Publishing, Wallingford, UK.

9. Tripathi B (2008) Chikitsa Sthan 15/43, Charak Samhita Part 2, Chaukhambha Surbharti Prakasan, Varanasi, India. Pg no: 367.

10. Tripathi B (2008) Chikitsa Sthan 1/7, Charak Samhita Part 2, Chaukhambha Surbharti Prakasan, Varanasi, India. Pg no: 5.

11. Srikanth N, Dua M, Bikshapathi T (2006) Butea Monosperma root distillate eye drops (PalasaMoolaArka) in age related immature cataract: A clinical observation. J Res Ayurveda and Siddha 27: 12-23.

12. Rege N, Bapat RD, Koti R, Desai NK, Dahanukar S (1993) Immunotherapy with Tinospora cordifolia: a new lead in the management of obstructive jaundice. Indian J Gastroenterol 12: 5-8.

13. Bichile LS, Rajadhyaksha A, Kini S, Parikh HS, Karkera SG (2001) Double blind randomized controlled trial of Sallaki vs Diclofenac in treatment of Rheumatoid arthritis. The Indian Practitioner 54: 625-632.

14. Central Council for Research in Ayurveda and Siddha (1989) Clinical and Experimental trial of Guggulu in Medoroga (lipid Disorders). Central Council for Research in Ayurveda and Siddha, Ministry of Health \& Family Welfare, Government of India, Janakpuri, New Delhi.

15. Kuppurajan K, Rajagopalan SS, Sitaraman R, Rajagopalan V, Janaki, et al. (1980) Effect of Ashwagandha (Withania somnifera) on the process of ageing in human volunteers. Journal of Research in Ayurveda and Siddha 1: 247258.

16. Central Council for Research in Ayurveda and Siddha (1990) Management of Hemiplegia by Panchakarma therapy. Central Council for Research in Ayurveda and Siddha, Janakpuri, New Delhi.

17. Brindavanam NB, Bhattacharya N, Katiyar CK, Narayana DBA (2002) Multi-facetted protective Role of Rasayana Therapy: A review of investigations on Chyawanprasa. Ayurvedic Conference on Rasayana 2002, Rashtriya Ayurveda Vidyapeeth, India. 
18. Kuppurajan K, Seshadri C, Rajagopalan V, Srinivasan K, Sitaraman R, et al (1992) Anti-anxiety effect of an Ayurvedic compound drug - A cross over trial. Journal of Research in Ayurveda and Siddha 13: 107-116.

19. Pradhan K (2014) Management of Stresses and Strains in Old Age. Indian Journal of Research in Multidisciplinary Studies 1: 139-145.

20. Zettergren KK, Lubeski JM, Viverito JM (2011) Effects of a Yoga program on postural control, mobility, and gait speed in community-living older adults: a pilot study. J Geriatr Phys Ther 34: 88-94.
21. Chong CS, Tsunaka M, Tsang HW, Chan EP, Cheung WM (2011) Effects of Yoga on stress management in healthy adults: A systematic review. Altern Ther Health Med 17: 32-38.

22. Chen KM, Wang HH, $\mathrm{Li} \mathrm{CH}$, Chen MH (2011) Community vs. institutional elders' evaluations of and preferences for Yoga exercises. J Clin Nurs 20: 1000-1007.

23. O'Connell H, Chin AV, Cunningham C, Lawlor B (2003) Alcohol use disorders in elderly people--redefining an age old problem in old age. BMJ 327 : 664-667. 